\title{
The Holonic Christ: Catholicity as Individuation and Integration
}

\author{
Robert Nicastro
}

Citation: Nicastro, Robert. 2021. The Holonic Christ: Catholicity as Individuation and Integration. Religions 12: 686. https://doi.org/ $10.3390 /$ rel12090686

Academic Editor: Ilia Delio

Received: 15 July 2021

Accepted: 24 August 2021

Published: 26 August 2021

Publisher's Note: MDPI stays neutral with regard to jurisdictional claims in published maps and institutional affiliations.

Copyright: (c) 2021 by the author Licensee MDPI, Basel, Switzerland. This article is an open access article distributed under the terms and conditions of the Creative Commons Attribution (CC BY) license (https:// creativecommons.org/licenses/by/ $4.0 /)$.
Department of Theology and Religious Studies, Villanova University, Villanova, PA 19085, USA; rnicastr@villanova.edu

\begin{abstract}
The paradigm shift ushered in by the new science of the early twentieth century discloses the universe as a dynamic, energetic, and complex web of relationality. In view of this renewed sense of undivided wholeness, this article seeks to advance the growing synthesis of theology and depth psychology by way of a revised meaning of catholicity. Specifically, the article utilizes Carl Jung's theory of individuation to suggest that catholicity is the conscious movement of the psyche toward wholeness, an outcome that Jung associated with Christ. The article introduces the term "Holonic Christ" to describe Christ as both the regulating principle of wholeness in nature and the co-recipient of the activity of deepening wholeness through the psychological development of the self-reflective individual. In this way, the article contends that catholicity is the process of individuation in its fullest form: a dynamic energy of the psyche that urges us in the direction of a more integrated personality, an ever-expanding community, and an eschatological remediation of divine self-contradiction made possible by human self-actualization. The article concludes with a discussion of the far-reaching religious implications of this study and explains why this new understanding of Christ is valuable to theological discourse.
\end{abstract}

Keywords: catholicity; Carl Jung; individuation; consciousness; holon; Christ; symbol; wholeness; cosmology; science and religion

\section{Introduction}

In recent years, the concept of catholicity has come under renewed scrutiny. It is derived from the Greek word, katholikos, which is best defined as "throughout the whole" or "a sense of wholeness". The early Greeks coined the term to describe their relationship to the cosmos, their "sense of the whole physical order of things" (Delio 2015, p. xi). Hence, the very essence of catholicity flowed from their understanding of cosmology. Given the insights of contemporary science, however, our understanding of the wholeness of reality has fundamentally changed. Rather than the static, perfectly ordered, and completely coherent Aristotelian-Ptolemaic worldview that governed the thinking of the Greeks, the paradigm shift ushered in by Big Bang cosmology, quantum physics, and biological evolution discloses the universe as a dynamic, energetic, and unfolding web of undivided wholeness. Indeed, all of life, the physicists tell us, is impregnated with some degree of consciousness, a mysterious mental quality that increasingly advances toward higher sentience through the unifying process of evolution. "As human beings and societies we seem separate", David Bohm explains, "but in our roots we are part of an indivisible whole and share in the same cosmic process" (Bohm 1980, p. 5).

The twentieth-century Swiss psychiatrist Carl Jung comprehensively grasped the revelations of the new cosmology. He reverenced the irreducible complementarity of mind and matter and so likened the slow, processual birth of thought to an unconscious numinous dimension implicit in the unfolding of the universe. In Jung's estimation, God is the fullness of undifferentiated life- a vast and eternal reservoir of unrelieved polaritieswhose very completion is contingent upon the psychological development of the human person in whom the reality of the Incarnation subsists. The immanent unification of God, in other words, is the meaning and purpose of history; it is a project of divine resolution and 
unification in human consciousness. As a result, Jung identified the figure of Christ as the archetypal symbol of wholeness, a reality he called the self, which pointed to the complete integration of God and humanity, the unconscious and consciousness. For him, the mutual embrace and differentiation of all opposites in the great enterprise of divine-human cocompletion depends on the entire human community. He called this equally individual (psychological) and collective (eschatological) dynamic the process of individuation.

The amount of ink spilled on the intricacies and implications of Jung's impressive body of literature is staggering. His work is surely a living document that continues to grow with its readers. With the intention of sustaining the growing synthesis between theology and depth psychology, the hope of this article is to demonstrate the legitimacy of Jung's theory of individuation by way of a revised meaning of catholicity. As catholicity describes "the essential [psychic] nature of reality" (Delio 2015, p. 9), the renewed sense of wholeness communicated by modern science allows for the reinterpretation of catholicity as the holonic energy of divinity impelling our consciousness to greater degrees of wholeness. Consonant with the root of catholicity, holon means "whole" and describes the character of relational wholeness at the heart of existence. Each part of life is an individual and evolving system of wholeness that emerges from a larger system of wholeness, which this paper names the "Holonic Christ". To that end, I will suggest that catholicity, as a conscious movement toward greater wholeness, is the process of individuation in its fullest form: a dynamic energy of the psyche that urges us in the direction of a more integrated personality, an ever-expanding community, and an eschatological remediation of divine self-contradiction made possible by human self-actualization.

\section{The Tripartite Relationship: Catholicity, Cosmology, and Christ}

The early Greeks were keen observers of the natural world. They inhabited the worldview as conceived by Aristotle and Ptolemy: a three-dimensional, fixed, and perfectly synchronized universe, of which they understood themselves to be an integral part. As a result, they coined the term catholicity to describe their awareness of standing in relationship to the cosmos; it conveyed their conscious disposition of the entire structure of reality. For them, catholicity and cosmology were intimately interrelated, and to embody catholicity was to live in deliberate harmony with this sense of wholeness.

While the Greeks appreciated catholicity as human consciousness of the cosmos, Christians took possession of catholicity to express a consciousness of Christ as the one through whom this wholeness was centered (Delio 2015, p. 10). In a religious sense, the world as the body of Christ renders Christ a new symbol of wholeness. As the physical structure of the world, Christ nourishes, holds togethers, and orients all things toward their future fulfillment in the Total Christ. In his letter to the Ephesians, Saint Paul corroborates: "[A]s a plan for the fullness of time, to gather up all things in [Christ], in heaven and things on earth" (1:10) [ ... ] "[Christ's] body [is] the fullness of [the one] who fills all things" (1:23). [ . . ] "In [Christ] the whole structure is joined together and grows into a holy temple in the Lord" (2:21). As the core and goal of the universe, Christ is the principle of order who sanctifies the nature of wholeness through the life of the Spirit.

Unlike the static, hierarchical, and conspicuously predictable worldview of the early Greeks and Christians, the new cosmology of the early twentieth century has radically altered our perceptions of existence. The universe we now know is ancient, expanding, dynamic, evolving, and fundamentally comprised of energy. This brave new world of energetic wholeness reveals all of life as complex webs of relationships. Such a reality paves the way for a renewed meaning of catholicity grounded in Christ, for when our understanding of the world changes, so too does our consciousness.

\section{Mind in Matter}

The new worldview initiated by the discovery of quantum physics and the universal power of evolution have furnished us with new philosophical language by which to interpret our sensory experience more accurately. The empirical evidence of quantum 
mechanics, for instance, identifies the feature of mind at even the most rudimentary level of existence, and thus renders the once mainstream position that mental and physical properties are somehow rigidly distinct from one another no longer tenable. Rather, the mental and material are two equivalent and interdependent aspects of the same reality. They are together necessary and indispensable to comprehend the world. ${ }^{1}$ Twentieth-century evolutionary biologist Julian Huxley writes of this deep intelligence and interconnectedness at the heart of materiality:

[The fact and logic of evolution] demand that minds should have evolved gradually as well as bodies and that accordingly mind-like [ ... ] properties must be present throughout the universe. Thus, in any case, we must infer the presence of potential mind [ ... ] by backward extrapolation from the human phase to the biological, and from the biological to the inorganic [ ... ] The brain alone is not responsible for mind, even though it is a necessary organ for its manifestation. (Teilhard de Chardin 1959, pp. 16-17)

Enamored of this primordial mind-matter mutuality, physicist David Bohm elaborated on the notion of emergent consciousness through the physical complexity of evolution. In his magnum opus The Undivided Universe, he writes of this bottomless depth of inwardness and explains that "active information [serves] as a bridge between the mental and the physical" (Bohm 2002, p. 386). He further postulated that such active information is analogous to an "unconscious background of explicit consciousness" (Bohm 1980, p. 267), a "greater collective mind" (Bohm 2002, p. 386) in which humans participate and in whom this mind "has created a mirror to observe itself" (ibid., p. 389). ${ }^{2}$

The presence of some active mind-like quality streaming its way through the process of evolution and culminating in the emergence of reflective consciousness was equally integral to several of Jung's theories. A contemporary of Bohm and Wolfgang Pauli, he was deeply influenced by the new science and privileged human participation as giving rise to what he identified as an archetypal cosmic order-a principle of regulating wholenessembedded within the evolutionary process. In contrast with Huxley's largely secularist approach to the complex interaction between consciousness and matter, Jung associated Bohm's idea of some "greater collective mind" with a numinous dimension implicit in the unfolding of the universe, an unconscious God immanent in matter itself, whose unconscious aspects are progressively made conscious in and through the psychological development of the self-thinking individual.

In recognition of Jung's assiduous contemplation on the life and meaning of Jesus Christ, Peter Todd explains: "Jung quite specifically writes of the evolution of God according to the archetype of the coniunctio oppositorum [union of opposites] or wholeness. He [treats] God (and Christianity) as a patient in analysis for whom consciousness needs to be brought into [God's] unconscious darkness in a self-transformative process, one of individuating and becoming whole" (Todd 2017, p. 65). ${ }^{3}$ According to Jung, God achieves this process of higher and expanded consciousness through ongoing Incarnation in humankind. The two-fold assumption couched in this claim is that humanity bears an intrinsically divine status and God requires humanity to become both whole and complete. Todd asserts: "God and humanity are in an entangled state and the individuation of each is inextricably bound with the other. In other words, the evolution of God and the evolution of humanity cannot be separated. Christ is a symbol of the self and of the coniunctio, since Christ in Jung's thought reconciles opposites" (Todd 2013, p. 13). ${ }^{4}$ It is precisely God's transformation in the consciousness of finite entities that more deeply unifies and divinizes the world.

\section{Christ as the Symbol of the Self}

The inner world of the psyche is a limitless wellspring of untapped creativity that arouses exploration and discovery. The mystery at the heart of existence is similarly present within this depth, continually challenging us and crying out for greater expression. The divine life at the center of our lives, in other words, is an infinitely fecund source of undiffer- 
entiated psychic energy seeking to generate itself through the activity of the ego, the center and content of our consciousness. ${ }^{5}$ As the vast majority of our undifferentiated psychic energy is absent to our consciousness, yet fully present in the realm of the unconscious, Jung referred to the unconscious as the creative source for the materials of consciousness and consequently believed it co-responsible for the full burgeoning of personality, an outcome that Jung called the self.

The self is the archetype of wholeness in the psyche-the pattern of meaning that guides the developing personality to continual growth. It represents both the circumference and the center of the personality. As such, the self is the personality's fundamental orientation toward wholeness; it concurrently animates the intensifying synthesis between consciousness and the unconscious and expresses the moment when the psyche has reached absolute balance and harmony. Archetypes that are known to consciousness become actualized through symbols. For Jung, symbols are forever pregnant with meaning; they serve as the best possible explanations of those enigmatic elements of the psyche that are never entirely disclosed to our conscious awareness. They bear the responsibility of transforming the energy in the unconscious-that which is undifferentiated-into an equivalent conscious form. In this respect, the symbol expresses a specific yet ongoing formation of the unconscious in consciousness.

As an empirical scientist with deep-seated Christian sensibilities, Jung ascribed the unfathomable content of the unconscious to the continual process of Incarnation in human consciousness. Though the figure of Christ embodies a unique and important history, Jung was adamant that the significance of Christ must extend beyond the historical and resurrected person; Christ is rather paradigmatic of the inner life and ultimate goal of integration for all humanity. He expounds: "There is God-archetype embedded within the psyche, an inexhaustible and overwhelming psychic factor that is like an endless spring of flowing water. It is the depth of psyche, the unknown and incomprehensible material of our potential, of our growth into personality" (Jung 1969, p. 11). As the referent of this numinous and transformational archetype is "unknown and incomprehensible", Jung gave it the psychological appellation of self-the central archetype in the collective unconscious calling the personality to order and unity. This God-archetype conveys both "the essence of human wholeness and expresses the indescribable and indeterminate nature of this wholeness" (ibid., p. 20). As a result, images of God are likewise images of the self, for "the self cannot be distinguished from an archetypal God-image" (ibid., p. 238). There is an interrelationship between the God-image and the self to such a degree that "the destruction of the God-image is followed by the annulment of the human personality" (ibid., p. 170). Accordingly, Christ, who is the image of the invisible God, likewise refers to the self; Christ is simultaneously a divine image and a self-image. Jung clarifies: "The Christ-symbol is of the greatest importance for psychology insofar as it is perhaps the most highly developed and differentiated symbol of the self" (ibid., p. 22). He maintained that the descriptions found in scripture were helpful in corroborating the Christ-symbol as our psychological base, a reality that should make us eminently mindful of our intrinsic interrelatedness with the divine. He recounts:

[Christ] is in us and we in [Christ]. [Christ's] kingdom is the pearl of great price, the treasure buried in the field, the mustard seed which will become a great tree, and the heavenly city. As Christ is in us, so also is [Christ's] heavenly kingdom. These few, familiar references should be sufficient to make the psychological position of the Christ symbol quite clear. Christ exemplifies the archetype of the self. (ibid., pp. 69-70)

As the exemplification of the archetype of the self, Christ represents our capacity for the fullness of life. The broader, richer life available to us, yet unknown and latent to our consciousness, discovers its actualization in Christ, who is the sheer depth of rationality. This seemingly quiescent, though ever-present wellspring of animation is driving and drawing human consciousness to new and limitless horizons of insight, as the infinite within is the seed and co-recipient of becoming, endlessly seeking fuller realization in those 
who cannot help but remain finite. The conscious release of this transformative energy welling up from our unconscious origin is known as the process of individuation. It seeks the culmination of individual consciousness as its moves toward the embrace of the totality at the internal insistence of the same energy that enables both the flowering of mind and the totality and remains their active substrate (Dourley 2015, p. 105).

\section{The Individuation Process}

The individuation process is the chief concern of Jungian psychology. It describes the process whereby the neglected unconscious begins to emerge through the development of personality. Jung explains: "Individuation is the process by which individual beings are formed and differentiated; in particular, it is the development of the psychological individual as a being distinct from the general, collective psychology. Individuation, therefore, is a process of differentiation having for its goal the full development of the individual personality" (Jung 1969, p. 757). This differentiation process requires that the individual attends to the poles of the psyche that, when integrated together, constitute the self, or psychic totality of one's being. Once these parts of the psyche breach awareness-that is, once consciousness and the unconscious engage in intentional communication and give rise to the aspects of the self that are seeking expression in conscious living - then the undivided state of the psyche allows for the generation of a unique personality.

Given Jung's appreciation of Christ as the symbol of self, he held that the journey of the psyche through the process of individuation is quintessentially expressed in the dogmatic positions of Christianity. The self is the psychological equivalent of the kingdom of heaven, which exists within each person as our divinely grounded center. For Jung, the self is not merely God, but the symbol of Christ as perfectly representational of the self is indistinguishable from the reality of God as our powerfully emerging center, which persistently begs our attention and demands our response. He writes of this indescribable call to conscious union:

At this point, unpalatable as it is to the scientific temperament, the idea of mystery forces itself upon the mind of the inquirer, not as a cloak for ignorance but as an admission of is inability to translate what he knows into the everyday speech of the intellect. I must therefore content myself with a bare mention of the archetype which is inwardly experienced at each stage of individuation, namely, the slow birth of the 'divine child' or-in the language of the mystics-the inner [person]. (ibid., p. 482)

\subsection{The Principle of Opposites}

Central to Jung's discussion of individuation is the energetic movement of the psyche. The movement of the psychic processes depends upon the principle of opposites, which results from the dynamic tension between opposing forces, or more generally speaking, the frequently schizophrenic intercourse between the inner and outer world. In other words, all significant opposites are contained within God as the unconscious source of reality, but remain "undifferentiated because of the absence of discriminating reason of the kind possessed by the human ego" (Dourley 2008, p. 104). The successful reconciliation of these conflicting forces is contingent upon ongoing Incarnation in human consciousness. ${ }^{6} \mathrm{Jung}$ expounds:

One should make it clear to oneself what it means when God becomes man. It means nothing less than a world-shaking transformation of God. It means more or less what creation meant in the beginning, namely, an objectivation of God. At the time of creation, he revealed himself in nature; now he wants to be more specific and become man. [ ... ] The future indwelling of the Holy Ghost in man amounts to a continuing incarnation of God. Christ as the begotten son of God and pre-existing mediator is a first born and a divine paradigm which will be followed by further incarnations of the Holy Ghost in the empirical man. (Quoted in Todd 2017, p. 66) 
In direct contradistinction to the fundamental propositions of Christianity, Jung evolves his principle of individuation from the standpoint of good and evil as an equivalent and indispensable pair of opposites-a method that encompasses both experiential feeling assessments and universal human value judgments. Since divinity is the unconscious ground of the psyche, and since psychological development depends upon the struggle and interplay of polarities in the psyche, both good and evil must necessarily be present in God. Jung writes: "They [good and evil] are a logically equivalent pair of opposites and, as such, the sine qua non of all acts of cognition. From the empirical standpoint we cannot say more than this. [ . . . Unlike the idea of privatio boni,] evil must therefore be taken more substantively on the plane of empirical psychology" (Jung 1969, p. 84). ${ }^{7}$

As we have departed from the static ("essentialist") concept of reality to a dynamic, evolutionary one, Jung's approach renders Christ a much more suitable symbol of the self, and nicely recasts the classical Christological dogma in terms that are more accessible, credible, and meaningful in our contemporary context. More specifically, Jung's contention that God's self-manifestation perdures through the self-directed consciousness of the intellectual subject and is not restricted to its historical particularity, as important as it may be, brings the traditional Chalcedonian stance of the two natures of Christ and depth psychology into greater synthesis. Dourley illuminates this point:

The Council of Chalcedon's description of Christ as possessed of two natures in one person becomes a description of the processes of individuation brought to full consciousness in Jung's psychology. The two natures present in everyone are those of consciousness [the ego] and the unconscious [God] whose unification works toward divinization [Christification] of the person to the extent their unification is approximated in the person. For Jung the simple awareness of the divinity of what is in the individual and in nature marks the point to which the religious instinct has currently evolved. (Dourley 2011, p. 524)

Thus, the continual exchange between the ego and the unconscious, the human and divine, is precisely the substance of individuation; it is the experiential material through which the psychogenesis of divinity emerges and the formation of the self is realized.

As individuation requires us to suffer through the "passion of the ego" (Jung 1969, p. 233), Jung found the image of the crucified Christ a more holistic image to effectively capture the paradox of the equivalent contraries endemic to the development of the self. The power of this image reveals the presence of evil while simultaneously transforming it through the mystery of crucifixion. The archetypal polarity is portrayed by the figures of the criminals—one good and one bad—crucified on either side of Christ as the symbol of wholeness. Dourley details this depiction:

[Jung's] interpretation of the crucifixion implies that the opposites between whom the Christ figure dies are themselves grounded in the archetypally divine. Further Christ's dying cry of despair at being abandoned by the Father expresses his consciousness that no help can come from a divinity wholly external to the psyche. The suffering of Christ is that of humanity universally caught between divinely grounded polarities and charged with uniting them in itself through the suffering to the point of death of the consciousness crucified between legitimate archetypal opposites. Only through such death can a resurrected consciousness arise now able to bring together the lethal conflict of the conflicted consciousness it transcends. [ ... ] The conscious suffering of divinely grounded opposites leads to an always more inclusive and synthetic consciousness. The transcendence involved does not point beyond the process itself but to the process itself, a process in which humanity suffers the divine contradiction to conscious resolution as the base meaning of human existence. (Dourley 2008, pp. 105-6)

\subsection{An Inclusive and Synthetic Consciousness}

The assertion that the process of individuation "leads to an always more inclusive and synthetic consciousness" (ibid., p. 106) is especially noteworthy. Jung is unmistakable 
that the paschal cycle of death and resurrection ceaselessly perdures as the unconscious is inexhaustible transcendence itself; it is expressive of the infinite fecundity of divine life. Dourley affirms: "As states of more inclusive consciousness succeed each other historically or individually they are challenged even as they appear to include yet more of the underlying divine wealth seeking consciousness in the ever-broader patterns of synthesis such extended inclusiveness and compassion achieve in consciousness" (ibid., p. 106).

Thus, the dynamic psychological drama of individuation - the totality of divinity becoming conscious in human consciousness-quite literally depends on the ability of humanity as a corporate body to usher divinity into consciousness. The reconciliation of divine opposites in historical consciousness is both an individual (psychological) and collective (eschatological) achievement. This "both-and" phenomenon leads to a conscious wholeness that is forever more inclusive and synthetic, an ever-growing fullness of the self that urges "consciousness beyond its matrix to the community in which it finds itself [and] then leads consciousness [at each new stage of birth] back to its origins for its ongoing renewal" (ibid., p. 171). This psychical exchange between consciousness and the unconscious ultimately impels us toward a more integrated personality and ever-widening community, an eschatological remediation of divine self-contradiction made possible by human selfactualization. As such, it requires an attitude of catholicity, a desire to perceive and unite in consciousness the wholeness that lives as the depth dimension of every human person, a moral imperative to "release the wholeness at the heart of life yearning to become more whole in and through the human person" (Delio 2015, p. xiii).

\section{Recontextualizing Catholicity: The Holonic Christ}

Jung's methods showcase an intriguing amalgam of empirical science, naturalism, and religious sensibilities. Given this unique blend of interests, he was acutely aware of the importance of cosmology as he tried to make sense of the psychological role of divinity and humanity amid the historical circumstances in which he lived. In light of the revelations of modern science, particularly biological and cosmological evolution, quantum physics, and neuroscience, he radically departed from a metaphysics of substance, from a sense of divinity as self-sufficient in its transcendence over and against a humanity for which it has no intrinsic need and that, in turn, is divested of an innate sense of such a distant divinity (Dourley 2015, p. 107). Like Pierre Teilhard de Chardin and other contemporaries, he comprehensively grasped the "quantum wholeness" at the heart of our unfinished creation, and he likened this wholeness to the dynamic energy of divinity coming to birth, greater wholeness, and deeper union through the process of evolution. More specifically, Jung posited that divinity must create to complete itself, that is, only through reflective consciousness as the culmination of the evolutionary process is God able to grow in selfrealization and so progressively move humanity toward a more integrated community expressive of its very source. For Jung, therefore, the circumstance of consciousness was inherently linked to cosmology; an informed cosmology was vital for saying something worth saying about divinity and humanity, not to mention their integral interaction in the Christian mind. ${ }^{8}$

The critical connection between cosmology and consciousness is part and parcel of the concept of catholicity. In her book Making All Things New, Franciscan theologian Ilia Delio reminds us of its etymology. She explains:

Catholicity is [ ... ] about wholemaking. In its Greek origin, the world catholicity is a composite of the preposition kata (according to) and the noun holos (whole). Therefore, catholicity means according to the whole, or is "a sense of the whole physical order of things". [ ... ] Catholicity, like consciousness itself, is not static; it is not a fixed ideal. Rather, it is an outflow of human awareness in relationship to the surrounding world; it is like a connecting thread between the human person and the cosmos. (Delio 2015, p. 1)

The new cosmology, however, has given new meaning to the term catholicity "in a way anticipated by the Greeks but much more expansive" (ibid., p. 35). Delio comments: 
"Whereas the Greeks understood cosmos as that which is brought together by a sense of the whole order of things, modern science understands the deep interrelatedness between consciousness and matter" (ibid., p. 35).

\section{The Holonic Christ}

At the micro-level of our cosmic narrative, physicist David Bohm suggested that every part of life is entangled in an undivided wholeness, a position that stands at variance with classical physics (ibid., p. 121). ${ }^{9}$ Building upon Bohm's insights, journalist and social activist Arthur Koestler introduced the term holon to capture the pattern of deepening wholeness that results from the psychic progress of evolution-namely, the greater the complexity of physical life, the higher the interior levels of conscious life. Similar to the root of catholicity, holon means "whole" and describes the simultaneity of the wholeness of any entity by itself and its complex integration into a larger body of wholeness, whose singular identity is not dissolved or homogenized by this assimilation, but is preserved and enriched. ${ }^{10}$

As this profound interconnectedness now characterizes "the essential [psychic] nature of reality" (Delio 2015, p. 9), and, in a religious sense, Christ is the regulating principle in nature who connects each of us to the vaster eschatological body of Christ, catholicity can be reconceived as the dynamic consciousness of wholeness in nature-the holonic energy of divinity-impelling our consciousness to greater degrees of wholeness. We are all part of this "Holonic Christ" of unlimited potential from the beginning, and to somehow sever ourselves from this wholeness is to thwart the flow of life: The holonic movement in evolution working to complete both divinity and humanity, a total reconciliation of opposites that reveals that the life of each is utterly enriched only when they are consciously unified in mutual completion-the culmination of individuation. ${ }^{11}$

Jung believed that the construction of the self-the totality of divinity becoming conscious in human consciousness-required the participation of the entire human community. Like our psychic processes, if catholicity is a dynamic movement of consciousness itself toward greater consciousness, then to refuse the activity of catholicity-to seek the greater wholeness that is forever more synthetic and inclusive-is similarly to relieve oneself from the responsibility of individuation. The involvement in the process of individuation is the active movement toward a psychic totality, a completeness of the self, the full potential of one's personality actualized in Christ, who is the center and cause of all life and who is only completely complete in the psychic fulfillment of all life. It is an inner journey that carries one into the personal and collective layers of the unconscious, so that one might return to conscious living more aware of what has been ignored and thus more equipped to express more of oneself in the conscious personality: an individuated consciousness that enriches and integrates the "collective personality". To abrogate oneself from this process is to abandon not only one's own life, but the life of God, as the infinite fullness of the unconscious depends on each individual's ability to usher in divine consciousness. ${ }^{12}$ In this way, catholicity as a conscious movement toward greater wholeness is, in fact, the psychological movement of individuation in its fullest form.

\section{Catholicity as Individuation and Integration}

Jung described the symbol of Christ as representative of our capacity for the fullness of life, a latent condition of human consciousness that is slowly being realized as we grow in union with our divine center, as we seek to accomplish the work of personal and collective individuation. The crucial import for this section is that while the progressive development of the self unites consciousness with the unconscious in the personal integration of archetypal opposites, its full, powerful, and authentic actualization is necessarily "accompanied by an ever-greater sympathy of reality beyond the individual" (Dourley 2008, p. 107). The ongoing manifestation of God seeks an integration, a consciously undivided embrace, with all of existence. Thus, the greater the personal individuality, namely, the clearer the image of the wholeness that lies within, the greater the concern for the wider totality, the 
deeper the compassion, and the more purposeful the integration with the other. Indeed, this all-embracing posture for the sake of greater wholeness and union manifests as a truly catholic spirit.

In this vein, Jung argued that the maturing power of individuation constantly works to eradicate the pernicious seeds of narcissism and instead becomes an organic journey into richer communal living, a movement from the intensifying experience of the inner "we" to an intentional desire to intensify the experience of the outer "we". He expounds on this sense of catholicity:

Individuation has two principal aspects or movements: in the first place it is an internal and subjective process of integration, and in the second place it is an equally indispensable process of deepening the subject-to-subject relationship with the other. Neither can exist without the other. This double movement suggests that the physic development that arises from the unconscious should impel the individual to a spirituality that leads to human responsibility and inclusion and is effectively deepened by this interaction; the second suggests that as the divine becomes more conscious through the human, the human can become less mixed with the murky desires of the ego and more aware of the desires of the vision of divinity. (Jung 1969, p. 448)

The inner identification of the magnifying wholeness of divinity, in other words, requires its advance in all other identities. An individual may have a general indication of one's strengths from the personal work of individuation, for instance, but that work remains woefully deficient and held in abeyance without the presence of the other-whose own unique giftedness is the requisite stimulus for the genuine appreciation and eventual consummation of those strengths. Most important of all, this process enables the awareness of the neglected poles of one's personality: the areas of the unconscious that remain hidden, undeveloped, or simply ignored. It teaches that the voyage of individuation is a mutually reciprocal partnership of wholemaking, in which neither person threatens or dominates the distinctiveness of the other, but activates and promotes its fulfillment. Jung writes:

As nobody can become aware of [one's] individuality unless [one] is closely and responsibly related to [one's] fellow beings, the desire to withdraw to an egoistic desert in order to develop the self is not an option. [One] can only develop the self when [one] is deeply and unconditionally related to some, and generally related to a great many, individuals with whom [one] has a chance to compare and from whom [one] is able to truly differentiate [oneself]. (ibid., p. 592)

As a result, the development of the self is an indispensably interdependent endeavor. It begins with, and requires continual reinforcement from, the principle of catholicity: a conscious movement toward greater wholeness, a desire to deepen the unitive relationship among the aspects of life that are diverse (i.e., incongruous personalities). Such an orientation embodies a qualitative wholeness that is constitutive of the process of individuation, one that always implies more intensity, richness, and plenty as the very process itself is the holonic energy of life creatively working its way toward totalization. After all, Jung is unmistakable that the whole meaning of human history is a development of the self-an individual and collective, a psychological and eschatological movement of consciousness into its divine depths so that the divine might become increasingly more conscious in humanity through the reconciliation of its opposites. This is an ideal that requires each person to deliberately and responsibly incorporate all of one's personal suffering of divine conflict into one's unique individual experience and, as a natural effect, so move this one body of unified opposites toward the eschatological union, or wider history, of all opposites. Dourley elucidates this eschatological trek from the collective unconscious to collective consciousness:

The psychological movement of the individual caught up in the suffering of the divine is eschatological because the redemption in consciousness of the divine opposites operative in an individual life is the greatest contribution the individual 
can make to the movement of history and to the eschaton now cast as the ongoing resolution of the divine self-contradiction in universal human consciousness.

(Dourley 2008, p. 107)

Jung's theory of individuation (wholemaking) is a religious and psychological pursuit that will never be realized. The wealth of the collective unconscious will always transcend its present realization, constantly demanding further and greater entrance into the concrete circumstances of consciousness. For that reason, God as infinite fecundity will never truly be "all in all", but will forever remain the source of infinite possibility. With this premise comes the logical corollary that the situation of the human person will always remain infinitely complex, as the newly emerging aspects of our unconscious cry out for balance and reconciliation amid other differing and developing personalities. Nonetheless, the presence of others not only can help us name, claim, and reconcile our own neglected poles of the unconscious, but they too represent individual poles of personality, which we can help them to identify and integrate into their conscious personality. As a result, we can together assist one another in the process of individuation, to grow and mature into the deeper, wider life to which we are called by allowing divinity to experience divinity more fully in its ongoing Incarnation in the development of collective consciousness. In the end, the creation of the self is the fulfillment of the Holonic Christ. It is, indeed, a peculiarly catholic enterprise.

\section{A Succinct Summation of the Study}

As a depth psychologist, Jung utilized the field of empirical science and naturalism to probe the religious dimensions of the psyche. Deeply influenced by the new cosmology, particularly the wholeness in nature as revealed by quantum physics, he reconceived divinity as the psychic energy of evolution culminating and seeking in human consciousness greater wholeness and completion. For Jung, Christ fulfills the role of the self-the potential of complete unity of the conscious and unconscious-and presides over the entire process of human maturation, an activity of divine-human co-completion he called "individuation". God is the unconscious source of life to whom the repository of all undifferentiated opposites belongs, and through ongoing Incarnation, the archetypal polarities held within the infinite vastness of the unconscious become progressively unified through differentiation in human consciousness. The psychogenesis of divinity, in other words, slowly emerges in each new moment of individual (psychological) and collective (eschatological) suffering of that side of divine conflict in one's unique life. This personal act of divine-human resolution then contributes to the larger individuation process by moving this one body of unified opposites toward the eschatological union, or wider history, of all opposites.

Throughout this study, I have tried to argue that catholicity as a conscious movement toward greater wholeness is the psychological movement of individuation in its fullest form. It emerges as both an individual and collective process of psychic wholemaking, a universal vocation of personality enrichment given by God for the sake of God. This never entirely achieved objective reveals that only together do we have the potential to develop and employ our unique strengths to effectively identify and reconcile the disregarded poles of our unconscious. The ongoing process of individuation is one of mutual aid, of interdependent psychical exchange that ultimately impels us toward a more integrated personality, an ever-widening community, and an eschatological remediation of divine self-contradiction made possible by human self-actualization. It is, quite literally, an activity of catholicity that desires to release the wholeness at the heart of life yearning to become more whole in and through the human person.

\section{Conclusions}

\subsection{Every Center Is a Christ Center}

To enumerate the many implications of Jung's treatment of Christ requires a process of painstaking parsing that transcends the scope of this article. Nonetheless, a consideration of perhaps his most far-reaching implication of God as the ubiquitous matrix of consciousness 
is essential to this study. We recall that for Jung, Christ is the deep psychic center and goal of every human person, and so each of us has the capacity to manifest this mystical nature of wholeness uniquely in our lives: to move toward new moments of Incarnation and the future fullness of Christ. As union itself underlies all of reality, human persons only realize their authentic self in union with all of reality. Each person, therefore, must remain open to the otherness of all reality in order to realize and so complete the much deeper union that binds reality together.

Jewish philosopher Martin Buber once wrote of this phenomenon in terms of his "IThou" dynamic, an anthropological model that complements and supports Jung's theory of individuation. He noted that the mutual relationships of sharing and receiving with others enable the development of the self and help to identify and grow our unique particularity, namely, that "relation is reciprocity [individuation]" (Buber 1970, p. 62). I am who I am, in other words, only because of the persons with whom I am united.

As the core identity of God lay equally within each one of us, the pursuit of interreligious (and even non-religious) dialogue becomes a vital part of this quest for wholeness. In the broader sense of individuation, no longer is it intellectually honest or spiritually mature to claim a more comprehensive grasp or monopoly on the mystery of Christ. Rather, it is precisely the openness to and dialogue with others that becomes the indispensable medium through which the spiritual wisdom and insights of others can serve to deepen and coenrich identity and personhood. This engagement cultivates the non-dual consciousness necessary to see the world through the eyes of the one who is coming to be. Far from diluting core Christian beliefs, the foray into the project of individuation demands that we recognize every center as a Christ center and seek to advance the love that fastens all the centers to the one body of Christ. Thus, the sacred union that already binds us together invites us into dialogue and greater union with one another: to see the work of Christ everywhere, to respond in love, and to respect the diversity of humanity that develops our personalities and ushers God into consciousness.

\subsection{The Value of the Holonic Christ}

In an effort to launch the intellectual and spiritual renewal of Christ in the modern world, the Second Vatican Council was definitive: that humanity has progressed from a static concept of reality to a more dynamic, evolutionary one and that the new situation demands new efforts of analysis and synthesis (GS 5) (Paul VI 1965). Therefore, the Holonic Christ is valuable to theological discourse in that it presents another opportunity to recast the classical Christological dogma of Christ, which was situated in a static framework, into terms more accessible and meaningful in our contemporary context. Just as each generation of Christians expressed the significance of Christ through the employment of their own philosophical tools and contexts, this study offers a way to extend the universal importance of the Christ-event via a new synthesis of theology and depth psychology. More specifically, by way of explicit contrast to the traditional approach to Christology, this investigation has articulated the need to mature in our understanding of the mystery of Incarnation: to conceive of Christ not as a static, fixed, or complete entity, but as a spiritual and physical composite that is alive and growing through the psychological development of our lives. Incidentally, this notion not only recovers the sacredness of materiality, but is also much more consonant with Saint Paul's realization of Christ as the culmination and embodiment of what has preceded us, what is presently existing, and what is to come: "[T] he whole body, nourished and held together by its ligaments and sinews, grows with a growth that is from God" (Col. 2:19). As evolution's summit of physical complexity, we have a vital role to play in intensifying our psychic centers for the purpose of working with God to contribute to God's ongoing emergence and so add to the present degree of Incarnation: to recognize that we are systems of wholeness emerging from and ultimately responsible for the fulfillment of a larger system of wholeness.

Funding: This research received no external funding. 
Conflicts of Interest: The author declares no conflict of interest.

\section{Notes}

1 This philosophical stance is known as dual-aspect monism. German physicist Harald Atmanspacher explains: “For dual-aspect monism, where the underlying neutral domain is neither physical nor mental, complementarity thus implies that either the physical or the mental aspect is accessible in a given empirical context, although both of them are necessary for a complete picture" (6). To explore this concept further, see (Atmanspacher 2012).

2 Bohm's concept of complementarity - an active, underlying unity in which mind and matter function and mature as complementary manifestations - contributes scientifically to the theological center of Paul's Incarnational theology, namely, that the divine presence of Christ permeates our entire cosmic reality and is striving toward totalization (see Rom. 8:19-22; 1 Cor. 3:22 and 15:20-21; Eph. 1:10 and 4:10; Heb. 2:5-8).

3 In the mind of physicist Wolfgang Pauli and other adherents of the Copenhagen interpretation of quantum physics, the union of opposites or wholeness was directly reflective of the non-local effects, interconnectedness, and holism associated with both the quantum situation and the unconscious psyche.

4 It should not be overlooked that while Jung's focus is primarily on humanity-the persons in whom God is made "whole and complete" through the process of directed evolution-he does recognize the cosmic dimension of Christ. Todd mentions: "As a patient, God is clearly identified by Jung as a phenomenon of the collective unconscious, that is, as an archetype and as being coextensive with a cosmos which was evolving long before the origins of life and the eventual emergence of humanity". Not dissimilar to Teilhard de Chardin, the entire trajectory of evolution-from the Big Bang onward-is teeming with divinity; nothing is excluded from the process of sacralization. Nevertheless, the culmination (but not the termination) of the evolutionary process is on level of the intellectually conscious person, who is deputized with the moral task of "perceiving and uniting in its consciousness the living antimony which is the life of God in its depths" (Dourley 2008, p. 106). The human person, in other words, has the capacity to participate consciously or not in the cosmic narrative of unfolding wholeness. This notion is true of the Holonic Christ, as well. For more information, see (Todd 2017, pp. 65-68).

5 For Jung, there is a distinction between consciousness and the ego. While they are integrally related, consciousness is a specific part of the psyche - the totality of the personality-known directly and immediately by the individual. It encompasses all the thoughts, joys, struggles, memories, etc. that are present to one's awareness. In relationship to the unconscious-the undifferentiated aspects of the psyche-consciousness is the small portion of the psyche that is available to us. On the other hand, the ego, as indicated in the body of the text, is the center and content of consciousness. Its principal role is to serve as the gatekeeper to consciousness. As the gatekeeper, it filters the innumerable experiences of an individual's inner and outer worlds and admits only a limited set of experiences to his or her consciousness.

6 Jung's theory of individuation, or theogenesis, is remarkably similar to, if not reliant on, other ideas in the realm of process thought. In brief, the metaphysical framework of process theology was the brainchild of Alfred North Whitehead. He constructed a philosophical system in which he integrated the deeper implications of early twentieth-century science, particularly the revelations in quantum physics, Einstein's theory of general and special relativity, and biological and cosmological evolution. Rather than adhering to substance metaphysics, Whitehead observed the universe as a process of energetic relations and posited an organic and mutual relatedness between God and the world. God is immanent in the world and the world is immanent in God, and both are distinct fields of energy that unequivocally engage with and affect the other. In an attempt to offer a summative statement of his philosophy, he famously noted: "The world lives by its incarnation of God in itself". For more information, see (Whitehead 1978, pp. 342-52). For Jung, the rising circumstance of consciousness, especially on the level of the human mind, is a mirror upon which the universe has evolved to reflect upon itself and in which its very existence is revealed. As a psychoanalyst, he diverges from Whitehead in that he describes the evolution of God on the basis of the union of opposites, namely, the union of the self of God and the self of humanity. For an explication of this point, please continue reading the foregoing section on individuation.

7 "Privato boni" is translated as "the privation of the good". This notion originated from Saint Augustine in the fifth century. He argued that the character of evil is not some type of substance, but is a deficiency in the quality of our actualizing goodness.

8 Many traditional and commonly conservative theologies, especially in the Latin West, strive to achieve a balance between the relation of divinity conceived as transcendent (beyond the human and nature) and the relation of divinity conceived as immanent (within the human and nature), but all too often show partiality to the former. The idea of a wholly transcendent and self-sufficient God, one that is somehow discontinuous with created consciousness at best and only relating to it from a distance, is the product of the classical framework in which so much of our Christology in the West is still expressed. By employing Jung's method of individuation, the author is ultimately arguing for the need to adopt a more interdisciplinary and contemporary framework that reflects our lived experiences and responds to our present spiritual needs: the very aim of the Council of Chalcedon. Moreover, even Thomas Aquinas held that "a mistake in our thinking about nature results in a mistake in our thinking about God". (N.B.: As the article's hermeneutic is that of Jung's theory of individuation, the author only chooses to engage with the ideas of God that are directly relevant to this psycho-spiritual process.)

9 Whereas Bohm suggests a relational dynamic between parts as essential, classical physics understood parts as constituting wholes. 
In her book The Emergent Christ, Ilia Delio offers a helpful example to explain the greater depth (and consciousness) acquired through the holonic movement of evolution: "[A] whole atom is part of a whole molecule; a whole molecule is part of a whole cell; a whole cell is part of a whole organism. Similarly, we can see human persons as individual and yet as a part within a whole community, which is, in turn, within a whole society". For more detail, see (Delio 2011, pp. 29-31).

11 Following the logic of Saint Paul, the mystical poeticism of John the Evangelist, and Carl Jung, the Holonic Christ is steeped in the pre-existence of Christ. It posits the Incarnation of God in the Cosmic Christ as the fulfillment of natural evolution and thus looks to the Jesus of history-the chief personalization of Christ-as an apt description of the process of individuation. As truly God and truly human, Jesus serves as the archetypal model for actualizing and integrating our own God-centeredness (Lk. 17:21: "See [ ... ] the kingdom of heaven is within you"). Delio explains: "Jesus' deep oneness with God empowered his sense of catholicity, a non-dual consciousness of belonging to the whole and the whole belonging to God. He lived from this wholeness [in order to deepen this wholeness] by going 'all over Galilee, teaching in their synagogues, preaching the good news of the kingdom, and healing people from every kind of disease and sickness' (Mt. 4:23)" (Delio 2015, p. 74). As Jesus' inner oneness with God became externalized in his desire to develop community and abolish divisions, we too must come to recognize the wholeness that exists as the heart of our lives and seek to advance this wholeness in shared, communal life. While the historical Jesus is no longer physically present among us, the situation of the Risen Christ (the central focus of Pauline theology) subsists as the growing, developing, and maturing fulfillment of the world. Christ's body is a Cosmic Body that has a unique history, but is also a much larger physical reality that necessarily includes the entire universe: everyone and everything. As we are co-extensive with the universe, our collective task is to continue this evolutionary movement through our activities of catholicity.

12 In contrast with medieval theology, the Holonic Christ—in light of the new cosmology_affirms that divinity and humanity are interdependent and inescapable functions of each other. (N.B.: This position is consonant with the mystical experiences of Meister Eckhart and Jacob Bohme.) This ontological notion of divine-human entanglement suggests a mission of co-redemption (as is hopefully clear from the section on individuation). While God is the source of consciousness, God depends on humanity to resolve that "divine antimony" through ongoing Incarnation in its psychic integration. Dourley writes: "[C]onsciousness creates God as conscious and makes of God a creature of consciousness" (Dourley 2008, p. 171). Each new moment of psychological integration deepens the maturing wholeness of humanity and contributes to the completion of divine life.

\section{References}

Atmanspacher, Harald. 2012. Dual-Aspect Monism a la Pauli and Jung. Journal of Consciousness Studies 19: 1-22.

Bohm, David. 1980. Wholeness and Implicate Order. London: Routledge.

Bohm, David. 2002. The Undivided Universe. London: Routledge.

Buber, Martin. 1970. I and Thou. Translated by Walter Kaufmann. New York: Charles Scribner's.

Delio, Ilia. 2011. The Emergent Christ: Exploring the Meaning of Catholic in an Evolutionary Universe. New York: Orbis Books.

Delio, Ilia. 2015. Making All Things New: Catholicity, Consciousness, Cosmology. New York: Orbis Books.

Dourley, John. 2008. Paul Tillich, Carl Jung and the Recovery of Religion. New York: Routledge.

Dourley, John. 2011. Jung's Equation of the Ground of Being with the Ground of Psyche. Journal of Analytical Psychology 56: 514-31. [CrossRef] [PubMed]

Dourley, John. 2015. C.G. Jung and Pierre Teilhard de Chardin: Is There a Border Between Psychic and Evolutionary Energy? In Pierre Teilhard de Chardin and Carl Gustav Jung Side by Side. Edited by Fred R. Gustafson. Cheyenne: Fisher King Press.

Jung, Carl Gustav. 1969. Collected Works. Princeton: Princeton University Press.

Paul VI. 1965. Gaudium et Spes. December 7. Papal Archive. The Holy See. Available online: http://www.vatican.va/archive/hist_ councils/ii_vatican_council/documents/vat-ii_cons_19651207_gaudium-et-spes_en.html (accessed on 14 July 2021).

Teilhard de Chardin, Pierre. 1959. The Phenomenon of Man. Translated by Bernard Wall. New York: Harper and Row.

Todd, Peter. 2013. Teilhard and Other Modern Thinkers on Evolution, Mind, and Matter. Teilhard Studies 66: 1-24.

Todd, Peter. 2017. The Individuation of God: Integrating Science and Religion. Asheville: Chiron Publications.

Whitehead, Alfred North. 1978. God and the World. In Process and Reality. Edited by David Ray Griffin and Donald W. Sherburne. New York: The Free Press. 